This is the post print version of the article, which has been published in Accounting in Europe. 2018, 15(1), 33-54. http://dx.doi.org/10.1080/17449480.2018.1431398.

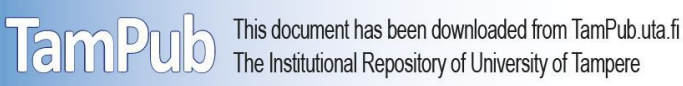

\title{
Responsiveness of auditors to the audit risk standards: Unique evidence from Big 4 audit firms
}

\author{
Lasse Niemi (corresponding author), \\ Aalto University, Business School, Runeberginkatu 22-24, FI-00076 AALTO, Finland
}

Tel. +358 40 3538058, email: lasse.niemi@aalto.fi

W. Robert Knechel

University of Florida, Fisher School of Accounting, Gainesville FL 32611, USA

Tel. 1-352-273-0215, email: w.knechel@warrington.ufl.edu

\author{
Hannu Ojala \\ University of Tampere, Kalevantie 4, 33100 Tampere, Finland, and Aalto University, Business \\ School, Runeberginkatu 22-24, FI-00076 AALTO, Finland \\ Tel. +35844 3290604, email hannu.ojala@aalto.fi \\ Jill Collis \\ Brunel University London, Brunel Business School, Kingston Lane, Uxbridge UB8 3PH, UK \\ Tel.+44 1895 266225, email: jill.collis@brunel.ac.uk
}




\title{
Responsiveness of auditors to the audit risk standards: Unique evidence from Big 4 audit firms
}

\begin{abstract}
We examine the effect of changes in audit risk standards on the conduct of financial statement audits in a European setting. We investigate this by analysing the audit hours and audit fees for clients of Big 4 audit firms in Finland in 1996 and 2010. Our results show that audit firms became more sensitive to clients' business risk due to the introduction of the new audit risk standards, with more audit hours allocated to owner-managed companies in 2010 than in 1996, and fewer audit hours allocated to lowrisk clients in 2010 than in 1996. Also, the labour mix in the audit team changed for owner-managed companies, with a greater work load carried by junior auditors in 2010 than in 1996. Regarding the price of audit, we find an increase in audit fees for clients with high business risk, while audit fees remained at roughly the same level for low-risk clients. These findings should be of interest to the auditing profession and those involved in the development of auditing regulations.
\end{abstract}

Keywords: Audit effort, audit regulation, audit risk, business risk approach

JEL Code: M42

\section{Acknowledgements}

We are grateful to the editor, Paul André, and the two anonymous reviewers for their valuable feedback on this paper. We are also indebted to the participating audit firms for giving us access to the data analysed in this study. In addition, we would like to thank David Hay, Juha Kinnunen, Bill Messier and delegates at the British Accounting and Finance Association Annual Conference in Newcastle (2013) and London (2014); the Annual Congress of the European Accounting Association in Paris (2013) and Tallinn (2014); and those attending the research seminars held at Aalto University Business School and Brunel University London for their helpful comments. We also gratefully acknowledge financial support from the Foundation of Helsinki School of Economics. 


\section{Responsiveness of auditors to the audit risk standards: Unique evidence from Big 4 audit firms}

\section{Introduction}

Over the past 15 years, efforts to stem the wave of financial scandals in large companies have resulted in substantial changes in the regulatory landscape and the way in which financial statement audits are conducted (Humphrey, Kausar, Loft \& Woods, 2011; Knechel, 2013). In many jurisdictions, the development of auditing regulation has moved from a national level to an international level. In addition, there has been a shift in the regulation of auditors from self-regulation by the accountancy profession to substantial oversight by government authorized bodies, coordinated through international networks (Humphrey \& Loft, 2013). A fundamental change in audit regulation between 1996 and 2010 was the introduction of risk-based ISAs that required greater documentation of the client's business risks (Curtis and Turley, 2005; van Buuren, Koch, van Nieuw Amerongen \& Wright, 2014). At the same time, auditing standards became more detailed and prescriptive, and greater emphasis was placed on assessing clients' risk in terms of operations, internal controls and management fraud. However, the question of whether audits have become more risk-oriented depends on how willing the auditor is to follow the new risk-based standards and how strongly they are enforced. The purpose of this study is to investigate the extent that the new risk standards are reflected in the auditing process.

The study is set in Finland which joined the European Union (EU) in 1995. At that time, guidance for auditors and quality checks in Finland were based on voluntary peer-review and recommendations provided by professional associations of auditors. However, in 2005, the European Group of Auditors' Oversight Bodies (EGAOB) was set up by the European Commission to co-ordinate a new public oversight system of statutory auditors and audit firms in EU Member States, which is enforced through a network of national oversight bodies. This was followed in 2006 by the Directive on the Statutory Audits of Annual Accounts and Consolidated Accounts (2006/43/EC). ${ }^{1}$ This meant that future guidance for auditors would come from International Standards on Auditing (ISAs) issued by the International Auditing and Assurance Standards Board (IAASB), the independent standard-setting body of the International Federation of Accountants (IFAC). In addition, the quality checks previously provided by 
the Finnish accountancy profession were replaced by systematic inspections by a national oversight body, the Auditing Board of the Central Chamber of Commerce (AB3C). ${ }^{2}$

Empirical evidence on the effect of the changing audit environment is scarce as information about the audit process at different points in time is extremely difficult to obtain. To the best of our knowledge, only Bell, Doogar and Solomon (2008) have undertaken a broad empirical assessment of changes in audit processes over time. Their study was set in the USA and examined the effect of the business risk approach to auditing that developed in the 1990s. Their results show that although fees and total audit hours were generally lower in 2002 than in 1992, audit effort by partners and managers was higher in general, and particularly high for riskier clients. ${ }^{3}$ The present study uses a unique set of fee and audit effort data for 140 clients of large international audit firms in Finland which allows us to provide empirical evidence on significant changes in the audit process between 1996 and 2010.

Our study contributes to the literature by extending our understanding of changes in the audit process from the mid-1990s to 2010 in a European setting. The European setting (Finland) is interesting because it experiences a lower risk of litigation than in the USA (Francis, 2004), so auditors becoming more responsive to client risk is likely to be driven by changes in standards rather than a fear of litigation. First, we provide empirical evidence that the introduction of new risk standards at the start of the millennium, together with the move from traditional transaction-based auditing to the business risk approach, has been reflected in auditors becoming more responsive to client risk. Audit firms becoming more sensitive to client risks is consistent with major changes in the regulatory landscape (Lennox, 2009) that occurred after the period studied by Bell et al. (2008) and led to increased scrutiny of audit quality and documentation of audit work. Second, we find empirical evidence suggesting that the difference in audit hours between low and high-risk clients increased over the period 1996 to 2010. Finally, we examine whether observed changes in auditor effort are reflected in audit charges and find that the business risks of clients are reflected in higher fees in 2010 than in 1996 . However, we find no reduction in fees for low-risk clients. These findings should be of interest to the auditing profession and those involved in the development of auditing regulations. 
The remainder of the paper is organized as follows. The next section describes the changes in the auditing environment in Finland and develops hypotheses on how the ways in which auditors carry out their work may have been influenced by these changes. We then provide a description of our methods and data, and report our results. We conclude with a discussion of the implications of the findings and the limitations of the study.

\section{Major changes in the auditing environment since the mid-1990s}

\section{Business risk approach}

In the 1990s, the major audit firms started developing new audit approaches based on a deep understanding of a client's business environment, plans and risks. Their methods were generally referred to as business risk auditing (Curtis \& Turley, 2007; Eilifsen, Knechel \& Wallage, 2001; Lemon, Tatum \& Turley, 2000; Peecher, Schwartz, \& Solomon, 2007; Robson, Humphrey, Khalifa \& Jones, 2007). ${ }^{4} \mathrm{~A}$ common feature of business risk auditing is a top-down analysis of the client's business risks linked to the audit risks of the engagement and conditioning the audit plan on the most critical of those risks. By the end of the 1990s, business risk auditing had been adopted in principle by most of the leading international audit firms. The underlying objectives of the approach were to increase the efficiency and effectiveness of auditing and give greater value to the client based on a deeper understanding of the client's business risks.

In the USA, Bell et al. (2008) studied the impact of the move from traditional transaction-based auditing to risk-based auditing on audit labour usage and audit fees between 1989 and 2002 . They expected that the increased emphasis on more complex risk assessments and audit judgments would lead to an increase in the proportion of senior auditor time relative to the total labour usage. They found that the total audit labour hours in 2002 were about 10\% lower than in 1989, but the total senior auditor hours were about $25 \%$ higher (an increase of about $40 \%$ in partner/manager hours). In Europe, a study of the application of business risk auditing at a Czechoslovakian bank in 1996 (Eilifsen et al., 2001) provides

similar anecdotal evidence. The study found a significant shift from substantive test evidence to 
evidence concerning risks, controls and performance measures, with less reliance on evidence from the documentation of individual transactions. At the same time, experienced staff and specialists had become more involved in the audit team.

\section{Introduction of new risk-based ISAs}

A second argument for audits becoming more risk-oriented is the introduction of new risk-based ISAs. At the start of the new millennium, major financial scandals, such as Enron, WorldCom, Ahold and Parmalat, led to calls for tighter oversight of auditors (Levitt, 2002) and caused many to question the efficacy of business risk auditing methods. Within a few years, professional guidance on risk-based auditing was fundamentally changed as the IAASB issued a suite of revised and new Audit Risk Standards: ISA 500 (revised), Audit Evidence, ISA 315, Identifying and Assessing the Risks of Material Misstatement through Understanding the Entity and Its Environment, ISA 330, The Auditor's Procedures in Response to Assessed Risks and an addition to ISA 200, Objective and Principles Governing an Audit of Financial Statements (IFAC, 2003). ISA 240, The Auditor's Responsibilities Relating to Fraud in an Audit of Financial Statements (effective from 2009) expands on how ISAs 315 and 330 should be applied in relation to risks of material misstatement due to fraud. ${ }^{5}$ Somewhat ironically, many of the precepts of business risk auditing were embedded in the new standards, particularly ISA 315 (Curtis \& Turley, 2005).

In Finland, the new risk standards were introduced in 2006 by the KHT Institute (the Finnish professional association of auditors), but there are two reasons why they may not have been reflected in audit work as intended. First, the consequences of auditor liability may be less severe in a low litigation environment like Finland and auditors might focus less on standards that they consider are too difficult to follow. To illustrate this, in 2014 the AB3C in Finland inspected the quality of the audits of 102 auditors and found that only $79 \%$ of the auditors passed the inspection, $15 \%$ were subjected to a re-inspection, and $6 \%$ were rejected. One of the main reasons for not passing the inspection was noncompliance with the ISAs. 
The second reason is that the status of the ISAs in the EU was unclear. Until the end of the 1990s, professional guidance for auditors in Finland was provided by the national professional associations, such as the KHT Institute and the Nordic Federation of Public Accountants (NRF). ${ }^{6}$ In 1995, when the first Auditing Act (936/28.10.1994) was introduced, supervisory bodies, such as AB3C, took over responsibility for quality assurance. However, the actual quality assurance work was still conducted by the professional associations until 2009, when the Auditing Board of the $\mathrm{AB} 3 \mathrm{C}$ introduced their inspection regime. ${ }^{7}$ From 2000 onward, this guidance was based on the ISAs, but initially these were regarded as recommendations for good practice rather than binding professional standards (Niemi \& Sundgren, 2008). This attitude changed when Finland passed the Auditing Act of 2007, which stipulates that auditors must comply with the ISAs. The Act also incorporates the requirements of the Directive on the statutory audit of annual accounts and consolidated accounts (2006/43/EC), which amended the Fourth and Seventh Company Law Directives (78/660/EEC and 83/349/EEC). However, none of the ISAs had been endorsed by the EU at that time.

Compliance with auditing standards has become a critical concern for audit firms due to the increased emphasis on ex post verification of the audit process. Since auditors are subject to potential secondguessing by inspectors, auditors want clear signals as to what they must do to pass an inspection. This has created a conundrum: although the emphasis on business risk suggests an increased need for professional judgment due to the idiosyncratic nature of each engagement, the inspectors will use the auditing standards to evaluate the quality of the engagement to encourage standardization across engagements (Knechel, 2013). Although ISAs are based on principles that allow auditors to exercise professional judgment, auditors can feel "increased pressures of conformity leading to a rise in checklists and tick-box approaches to auditing which place less emphasis on processes of professional judgment and more emphasis on a compliance with rules and procedures mentality" (Humphrey et al., 2011, pp. 446-7). Research in Australia by Dowling, Knechel and Moroney (2015) produced similar results. $^{8}$ 
On balance, it seems reasonable to assume that the risk standards are reflected in the auditing process, at least in larger audit firms with larger clients. This is because ISAs are enforced by oversight bodies such as the $\mathrm{AB} 3 \mathrm{C}$, which use them as a benchmark for assessing good auditing practice. Moreover, AB3C's quality inspection report in 2014 indicates that nearly all the auditors that did not pass the inspection were from small audit firms. ${ }^{9}$ Therefore, even in a low litigation environment like Finland, it is likely that the ISA risk standards are followed due to inspections by oversight bodies such as $\mathrm{AB} 3 \mathrm{C}$. Moreover, leading audit firms operate as international networks and tend to harmonize their audit methodologies across the network. We argue that the increased focus on the business risk has led auditors to adjust their audit processes over time to be more responsive to unique client risk concerns. The above arguments are reflected in our first hypothesis:

H1: Auditors were more responsive to the client risk in 2010 than in 1996.

The assessment of client risks and responses to those risks, as required by ISAs 315 and 330, play a critical role in audit planning which is primarily carried out by partners and managers. From Bell et al. (2008), we know that the move to audit methods emphasizing client risks increased the amount of senior auditor effort allocated to the audit of higher risk clients in the USA. The introduction of ISAs 315 and 330 , and their enforcement by outside inspections, also reinforces the risk-based approach in low litigation jurisdictions such as Finland. Therefore, we posit that senior auditors have become more responsive to client risks. This leads to our second hypothesis:

H2: Senior auditors (partners and managers) were more responsive to the client risk in 2010 than in 1996.

\section{Methods}

This study is based on the comparative analysis of a sample of audits conducted in 1996 and 2010. We start by describing the process used to collect the data and then analyse changes in the overall levels of audit effort and fees to assess the impact of changes in audit methods and regulation on the audit process. Ideally, we would use a difference-in-differences design with a control group that is not affected by the 
changes and a treatment group that is affected by them. However, as all audit firms are affected by changes in the audit environment, we can only measure the change over the period.

\section{Data}

To test our hypotheses, we collected proprietary data relating to the statutory audits of Finnish private and listed companies conducted by leading international audit firms at two points in time: 1996 and $2010 .{ }^{10}$ Our sample contains 81 audit engagements conducted in 1996 and 59 in 2010. Focusing on the leading international audit firms (the Big 6 in $1996^{11}$ and the Big 4 in 2010) helps control for variations in audit quality across audit firms and improves the comparability of our findings given the time gap between the audits. While many factors influence the audit process over such a long period, the increased focus on client risk and/or standardization should be reflected as systematic changes in the labour mix in the audit team and the drivers of audit effort and fees. Furthermore, the focus on relatively large, complex companies improves the comparability of our results to those obtained in countries such as the USA where data are only available for publicly listed companies. Financial and insurance companies are excluded since they may not be comparable to companies in other industries in terms of audit effort and fees.

For audits conducted in $1996,{ }^{12}$ we first identified clients of the Big 6 audit firms where the client had net sales exceeding 100 million Finnish marks (€16.7 million) using two sources: Statistics Finland's database of large Finnish companies and the database of auditors of large and medium-sized Finnish companies provided by Balance Consulting Ltd. Four of the Big 6 firms provided access to their internal audit records for 103 engagements (including audit hours) and participated in a questionnaire survey that was used to gather data on our variables of interest. We also obtained audit partner assessments of the quality of their clients' internal controls and the overall level of inherent risk for these engagements. The questionnaires were sent to a contact at each audit firm, who distributed them to the engagement partners responsible for the 1996 audits, and we received 81 usable responses (a response rate of 79\%). As we knew the identity of the client companies in the sample, we could supplement the survey data 
with publicly available financial statement data. Ownership data were hand-collected from the databases of the leading Finnish credit analyst company, Asiakastieto Oy, and other sources.

By 2010, the Big 6 audit firms had become the Big $4^{13}$ and the 2010 data were collected from one of the Big 4 that had participated in 1996. However, we were unable to obtain the identity of the engagement partners or the names of their audit clients. Staff at the participating Big 4 firm handled the collection of data on the behalf of the researchers after the random selection of 110 clients with net sales exceeding $€ 20$ million. A questionnaire was distributed to the relevant audit partners to gather information about each engagement that would allow us to compare 1996 and 2010 audits. We received 59 usable responses (a response rate of 54\%). To ensure the anonymity of the client companies, the number of subsidiaries was transformed to a 10-point scale using deciles of the distribution. To permit comparison, we performed a similar transformation for the 1996 subsidiary data.

\section{Statistical model}

To test our hypotheses, we use the following ordinary least squares (OLS) regression:

$$
\begin{aligned}
& \text { AUDITEFFORT }=\alpha_{0}+\alpha_{1} \text { CLIENT_RISK }+\alpha_{2} \text { CLIENT_RISK } \times Y 2010 \\
& +\alpha_{3} L N S A L E S+\alpha_{4} S U B S+\alpha_{5} I C Q U A L I T Y+\alpha_{6} I A F+ \\
& +\alpha_{7} \text { LISTED }+\alpha_{8} \text { MANUFACTURTING }+\alpha_{9} Y 2010+\varepsilon
\end{aligned}
$$

In equation (1), AUDITEFFORT is a measure of the effort expended by the auditor during the audit. We use three measures of auditor effort: (1) total audit hours by the audit team (LNTOTALHOURS), (2) audit hours worked by partners and managers (LNPTRMGRHOURS) and (3) the relative level of senior auditor and staff audit hours $($ LABOUR MIX $=L N(P T R M G R H O U R S / S T A F F H O U R S))$. With our third measure, we test whether changes in the auditing environment are reflected in the changes in the labour mix. We normalize our dependent variables using natural logarithms. ${ }^{14}$

(Table 1) 
We use three dichotomous variables (INHRISK, INVREC_HIGH, OWNERMANAGED) to capture various dimensions of client business risk that might indicate that audits became more risk-oriented after the introduction of risk-based ISAs. INHRISK is the engagement partner's self-assessment of the level of overall inherent risk, which is coded 1 for higher-than-average risk, 0 otherwise. Our second risk measure captures the 'difficult to audit' items, inventories and receivables (Hay et al. 2006). INVREC_HIGH is the relative amount of inventories and receivables and is coded 1 if the ratio exceeds the median for the sample, 0 otherwise. Our third risk variable captures the increase in professional scepticism required by ISA 240 (Nelson 2009). Under normal circumstances, owner-managed companies might be considered to have lower business risk than companies where the owners are not involved in the-day-to-day management because owner-managers have direct access to accounting records and place less reliance on audited financial statements. Agency costs are also lower in an ownermanaged firm, i.e., there may also be lower demand for auditing in owner-managed companies since there is less likelihood of information asymmetry that typically arises where there is separation of ownership and control (Fama and Jensen, 1983). ${ }^{15}$ Therefore, in the absence of fraud risk, auditors would generally consider risk to be lower for owner-managed companies because there are no owner/manager agency problems. However, due to new ISA 240, we expect that auditors will be less willing to accept assertions by management (whether owner-managers or professional managers) at face value. This suggests that even without owner-manager agency problems, auditors would have to increase audit work for owner-managed companies. OWNERMANAGED is coded as 1 if the firm is predominantly owner-managed $(>50 \%)$ and 0 otherwise. ${ }^{16}$ Because both our hypotheses require the comparison of the years 1996 and 2010, we augment equation (1) with interactions of our test variables (INHRISK, INVREC_HIGH, and OWNERMANAGED) and Y2010, which is coded 1 if the observations are from year 2010 and 0 otherwise.

We operationalise our hypotheses that auditors have become more responsive to clients' business risk in two ways. First, if the sum of the coefficients of the interaction variable $\left(\alpha_{2}\right)$ and $Y 2010\left(\alpha_{9}\right)$ is positive, it suggests that auditors have increased audit effort for audit clients with high business risk in 2010 compared to 1996. Second, if auditors have become more responsive to audit clients' business 
risk, clients with low business risk should require less audit effort in 2010 compared to 1996, as shown by a negative sign of variable $Y 2010\left(\alpha_{9}\right){ }^{17}$

We use six control variables in the models. We include client size (LNSIZE) because the size and complexity of operations affect audit effort (Bell et al., 2008; Hay, Knechel \& Wong, 2006; O'Keefe et al., 1994; Simunic, 1980; Simunic \& Stein, 1996). ${ }^{18}$ Client size relates directly to the volume of the operations and the number of business transactions, thus reflecting the amount of audit work required. We control for complexity of operations with the number of subsidiaries $(S U B S) .{ }^{19}$ From prior literature we know that the complexity of operations varies considerably across clients and can influence the audit effort required for an engagement (Bell, Peecher \& Solomon, 2005; Mock \& Wright, 1993; 1999; Stein, Simunic \& O'Keefe, 1994). We expect positive coefficients for LNSIZE and SUBS. We control for the client's investment in internal controls in two ways. Following O'Keefe et al. (1994), we measure the senior auditor's assessment of the overall quality of internal controls on a 5-point Likert scale (ICQUALITY). In addition, we add the dichotomous variable $I A F$, which captures whether the client has an internal audit function. $I A F$ is coded as 1 if there is an internal audit function and 0 otherwise. This is important because reliable controls can be used to justify a reduction in the substantive tests of business transactions (Ettredge, Reed \& Stone, 2000; Felix, Gramling \& Maletta, 2001; Gramling, 1999; Schneider, 1985). Prior research (Hay et al., 2006; Knechel \& Willekens, 2006; Hay, Knechel \& Ling, 2008) produced mixed results regarding the relationship between internal control and the level of audit effort. Therefore, we have no expected sign for these two variables. LISTED is a dichotomous variable that is coded 1 if the client company is listed on a stock exchange or belongs to a listed group and 0 otherwise. Companies with dispersed ownership present greater potential liability for an auditor (Simunic \& Stein, 1996). Therefore, we expect that LISTED will be positively associated with auditor effort. Finally, we control for industry-effects by including a dummy for manufacturing companies (MANUFACTURING) that is coded 1 if the firm operates in the manufacturing sector and 0 otherwise. We have no expectation on the sign of the coefficient for MANUFACTURING. We do not interact the control variables with year $(Y 2010) .{ }^{20}$ 


\section{Results}

\section{Descriptive statistics and tests of difference over time}

Table 2, Panel A (Panel B) presents descriptive statistics for the continuous (dichotomous) variables for 1996 and 2010. Panel A also reports the results of our tests of difference between the 1996 and 2010 samples, i.e., the equality of means and variance across time. Comparison of means and medians for our dependent variables (LNTOTALHOURS, LNPTRMGRHRS, LABOUR MIX and LNFEES) ${ }^{21}$ shows no significant differences between 1996 and 2010 except for LABOUR MIX. This is noteworthy in our further analyses on changes between these two points in time. However, the mean (median) of the hours to sales ratio (HOURS/SALES) decreased from 4.245 (3.417) in 1996 to 2.478 (1.757) in 2010 ( $p=$ 0.002 and $p<0.001$, respectively). While the audit fee/sales percentage was $0.035 \%$ in $2010,{ }^{22}$ the fees to sales ratio (FEES/SALES) in our sample did not change between 1996 and 2010. However, the mean of the senior auditor hours to total hours ratio (PTRMGR/TOTALHRS) decreased from 0.564 in 1996 to 0.475 in $2010(p=0.064)$, consistent with the view that the number of staff auditor hours relative to senior auditor (partners and managers) hours increased over the period 1996 to 2010. The statistics in Table 2 show no significant changes in the mean or median of the independent variables used in our tests (ICQUALITY, LNSALES, SUBS, INVREC_HIGH, IAF, INHRISK, OWNERMANAGED, LISTED or MANUFACTURING) and this helps alleviate potential bias due to the selection of companies for the two subsamples.

Table 2, Panel A also reports whether variances of senior auditor hours (LNPTRMGRHOURS) and junior auditor hours (LNSTAFFHOURS) changed between 1996 and 2010. The variance of LNPTRMGRHOURS increased (standard deviation is 1.135 in 1996 and 1.586 in 2010; $p=0.006$ ) while LNSTAFFHOURS decreased (standard deviation is 2.002 in 1996 and 1.371 in $2010 ; p=0.003$ ). ${ }^{23}$ The increase of variance of LNPTRMGRHOURS is consistent with greater responsiveness to idiosyncratic client risks by senior auditors, while the decrease in variance of LNSTAFFHOURS is consistent with less responsiveness to the idiosyncratic client risks by junior auditors (c.f. Knechel, Salterio \& Kochetova-Kozloski, 2010). However, these results should be interpreted with care because the 
variance of client size (LNSALES) also increased $(p=0.015)$, which is also likely to increase the variance in effort levels.

(Table 2)

Table 3 shows Pearson ${ }^{24}$ correlation matrices for our data for 1996 (below diagonal) and 2010 (above diagonal). As expected, the measures of audit effort (LNTOTALHOURS and LNPTRMGRHOURS) and audit fees (LNFEES) are positively correlated. LNSALES is positively correlated with all audit effort measures in 1996 and 2010, but the correlations are stronger in 2010. The same applies more clearly to SUBS. These findings suggest that audit effort has become more sensitive to client size and complexity. Turning to our variables of interest, comparison of correlation in 1996 and 2010 shows that audit effort and INHRISK are positively correlated in 2010, but not in 1996. INVREC_HIGH is not significantly correlated with audit effort or fees (except negatively with LNPTRMGRHOURS in 1996). For OWNERMANAGED, the correlation matrices show it is negatively correlated with the audit effort or fee measures in 1996, but these correlations are absent in 2010. Correlation between direct risk measure (INHRISK) and indirect risk measure (INVREC_HIGH) is insignificant in 1996 and in 2010, which suggests that in our setting an indirect measure does not capture business risk as efficiently as our direct measure. The correlation between INHRISK and OWNERMANAGED is positive and significant in 1996. This is consistent with our regression results reported in Tables 4 and 5 that show that the difference between both has increased significantly (see the results discussed in detail in the next section).

(Table 3)

\section{Client business risk and audit effort (H1 and $\mathrm{H} 2)$}

Table 4 (Panels A, B and C) and Table 5 report the results of our analysis of audit effort using an OLS regression model for the three different measures of audit effort (LNTOTALHOURS, LNPTRMGRHOURS, LABOUR MIX and audit fees (LNFEES). ${ }^{25}$ 
(Table 4)

Tests of total auditor effort

In Table 4, Panel A, we examine the effect of risk on total audit effort using our three definitions of risk. First, we consider INHRISK as a proxy for client risk. The coefficient for $Y 2010$ reflects the effect on LNTOTALHOURS when risk is low in 2010, which indicates that total audit hours decreased from 1996 to 2010 in the low risk condition $(-0.434, p=0.022)$, which translates to a $35 \%$ decline in audit hours for low risk clients between 1996 to 2010. When risk is high in 1996, as proxied by INHRISK, we find no effect on total effort in $1996(-0.040, p=0.450)$, However, we do observe a significant interaction of INHRISK and $Y 2010(1.025, p=0.050)$. This result is driven by the fact that auditors exert more effort on high risk clients in 2010 than they do on low risk clients in the same year $(0.984$, $p=0.071$ ). However, when we directly test high risk conditions between 1996 and 2010, we do not find a significant increase in audit effort between the two years $(0.591, p=0.158)$. These results partially support H1 because they indicate that auditors are more sensitive to risk in 2010 than in 1996, but this is mainly due to a reduction of effort on low risk clients rather than an increase in effort for high risk clients specifically.

When we define risk based on INVREC_HIGH, the results in Table 4 (Panel A) do not yield any significant coefficients associated with our test variables (including Y2010 and the interaction term). Thus, we find no evidence to support H1 when risk is measured based on the relative level of receivables and inventory.

Finally, we consider $O W N E R M A N A G E D$ as a proxy for client risk. When client is low risk (meaning not owner-managed) we observe a decrease in total effort in 2010 as evidenced by the coefficient for $Y 2010(-0.621, p=0.002)$. In this case, the reduction of audit hours is $46 \%$. We also see that effort is significantly lower in $1996(-1.344, p<0.001)$ for owner-managed clients. The interaction between OWNERMANAGED and Y2010 indicates that auditor effort is higher in 2010 when risk is high (1.205, $p<0.001)$. This is supported by the direct test of engagements that are high risk in 1996 compared to 
those that are high risk in 2010 . Here we see that auditors have become significantly more responsive to risk associated with owner-managed firms in $2010(0.584, p=0.031)$. This result suggests that effort increased 79\% for owner-managed companies between 1996 and 2010.

Note that inclusion of all three risk proxies simultaneously—see the last column—generally yields results that are consistent with the results for the model with only OWNERMANAGED included. The joint coefficients for the interactions of INVREC_HIGH and OWNERMANAGED with Y2010 are both significant $(-0.659, p=0.031 ; 0.606, p=0.080)$. In summary, the results for OWNERMANAGED support hypothesis H1, and with the limited findings for INHRISK, suggest that auditors are more sensitive to client risk in 2010 than in $1996 .{ }^{26}$

\section{Tests of effort by senior auditors}

Panel B of Table 4 reports the results for effort by senior auditors (managers and partners). This panel presents the results for our tests of hypothesis H2. For all definitions of risk, we see that effort by senior auditors was lower for low risk clients in 2010 than in $1996(-0.700, p=0.001 ;-0.736, p=0.007$; $0.707, p=0.002)$. For high risk clients in 1996, we see less senior effort for INVREC_HIGH $(-0.427, p$ $=0.048)$ and $O W N E R M A N A G E D(-0.916, p=0.002)$, but not for INHRISK $(-0.264, p=0.226)$. The interaction term is only significant for INHRISK $(1.454, p=0.017)$ suggesting that the effort of senior auditors is higher in 2010 than in 1996 when risk is high. The result for INHRISK appears to be driven by the differences in responses to high and low risk in $2010(1.189, p=0.049)$, rather than differential treatment of high risk clients across time, which is not significant $(0.754, p=0.123)$. Note that the results when all three proxies are included in the model are partially consistent with the separate models except INVREC_HIGH and the interaction OWNERMANAGED*Y2010 are not significant. Combined, the results reported in Table 4, Panel B suggest that senior audit hours for high-risk clients did not increase significantly, but for low-risk clients they decreased. This provides, at best, indirect support for hypothesis $\mathrm{H} 2$.

$\underline{\text { Tests of labour mix }}$ 
Finally, Panel C of Table 4 reports our results for $L A B O U R M I X$, i.e. the natural log of the ratio of senior hours to staff hours, LN(PRTMGRHOURS/STAFFHOURS). ${ }^{27}$ In Panel C, Y2010 is negative and significant using IHNRISK $(-0.670, p=0.041)$ and INVREC_HIGH $(-0.712, p=0.091)$, but not for OWNERMANAGED (-0.255, $\mathrm{p}=0.459)$. This suggests that there was a relatively lower level of senior auditor input into low risk audits in 2010. There are no other significant results for IHNRISK. The only other significant result for INVREC_HIGH is for the direct test of high risk clients in 1996 versus high risk clients in 2010. Here, we see that there is less relative senior auditor effort in high risk audits in $2010(-0.580, p=0.095)$.

When we turn to OWNERMANAGED, we see a significant change in labour mix between 1996 and 2010 as senior hours have decreased relative to staff hours for owner managed firms, as shown by the joint test of coefficients $(-1.949, p=<.001)$. This change also can be inferred from the earlier reported findings regarding Panels A and B in Table 4. Total audit hours of owner managed firms have increased $(0.584, p=0.031$, Table 4, Panel A), but senior hours have not $(-0.026, p=0.944$, Table 4, Panel B).

Note that when we add all three proxies to the model simultaneously, none of the test variables are significant so the labour mix seems to be uniquely conditional on OWNERMANAGED since the joint coefficient of the interaction term with Y2010 is significant $(-2.442, p=0.002)$. Taken together, these results show that junior auditor effort has increased relative to senior auditor effort between 1996 and 2010.

\section{$\underline{\text { Tests of audit fees }}$}

Table 5 reports the results from the fee regression. We do not observe a difference for low risk clients between 1996 and 2010, i.e., Y2010 is not significant using any of the risk proxies. We find a significant interaction effect in respect of INHRISK*Y2010 $(1.088, p<0.033)$ which is driven by both higher fees for high risk clients relative to low risk clients in $2010(1.006, p<0.026)$ and high risk fees in 2010 relative to high risk fees in $1996(1.066, p<0.029)$. INVREC_HIGH is not significant related to fees either as a main effect or in an interaction. Finally, we observe that fees for OWNERMANAGED clients 
in 1996 are lower $(-1,121, p<0.001)$ and the interaction with $Y 2010$ is significant $(1.059, p=0.002)$.

The latter result is driven by the fact that fees for owner-managed firms are higher in 2010 than they are in $1996(0.886, p<0.001)$. Inclusion of all three proxies simultaneously produces results that are generally consistent with the separate models and the interaction of OWNERMANAGED and Y2010 is significant $(0.752, p=0.074)$. These results are consistent with $\mathrm{H} 1$ in that audit fee results are more responsive to business risk in 2010 than in 1996, especially for owner-managed firms.

\section{(Table 5)}

Drawing our results together, for clients with high business risk, we find that between 1996 and 2010, total audit hours of manager-owned companies increased; staff hours increased relative to senior hours in the audits of manager-owned companies; and, for high INHRISK and OWNERMANAGED clients, audit fees increased. For clients with low business risk, we find that between 1996 and 2010, total audit hours decreased for companies with low INHRISK and for companies that are not owner-managed; senior auditor hours decreased across all three categories of low business risk (INHRISK, INVREC_HIGH, OWNERMANAGED); and audit fees have not decreased in any of the three categories of business risk.

\section{Additional tests}

We conduct additional tests related to changes in the audit environment. First, we estimate models like those reported in Table 4 with centred continuous variables and without interaction variables. The reason for using centring is that $Y 2010$ can then better capture the changes in overall auditor effort. The untabulated results are similar to those reported in Table 4, thus providing further assurance about our finding that auditor effort, particularly senior auditor hours, decreased from 1996 to 2010.

Further, we test the robustness of our findings in several ways. First, we repeat our main tests using only the same audit firms that appear in both years of the sample. Our results remain qualitatively unchanged. Second, we increase the comparability of 1996 and 2010 samples by removing 1996 audits that are smaller (in terms of total hours) than the smallest audits in 2010 (four audits). This does not 
change our inferences. Third, we examine the sensitivity of our results to our sampling procedure using a bootstrapping method (Efron \& Tibshirani, 1998) to perform a repeated resampling of data (untabulated). This yields similar results to our main tests, decreasing the likelihood that our results are due to chance.

\section{Conclusions}

This study contributes to the literature by extending our understanding of the effect of changes in the regulatory landscape during the period 1996 to 2010 in terms of the conduct of financial statement audits in a European setting. We analyse audit hours and their determinants and find evidence of several interesting developments.

First, our results show that audit firms have become more sensitive to client business risk, as the firms allocate more audit hours to owner-managed companies in 2010 than in 1996. Second, the labour mix in the audit team of owner-managed companies changed over the period from 1996 to 2010, with a greater workload carried by junior auditors. Third, we find an increase in inflation-adjusted audit fees for clients with high business risk. Fourth, we find that fewer audit hours are allocated to low-risk clients in 2010 compared to 1996, as measured by either total hours or senior auditor hours. Fifth, audit fees for low-risk clients have remained at roughly the same level. Taken together, our results regarding audit hours are consistent with the view that the adoption of risk-based auditing has increased the efficiency of audits. Combined with our results on audit pricing, we observe an interesting pattern. For high business risk clients, we observe an increase in audit fees, but there is no evidence of an increase in effort. In contrast, we find a reduction in audit effort for low-risk clients but no reduction in audit fees. We interpret this as the price of audit for high-risk clients attracting a premium for business risk after the introduction of the new risk standards, while no reduction of audit fees for low-risk clients reflects the 'stickiness' (de Villiers et al., 2014) of audit pricing.

Our study has some limitations. First, archival studies are limited to observation of associations rather than causality. It is possible that the observed associations between audit hours and client characteristics 
between the two points of time are caused by something other than the changes under study. Second, our analysis is limited to the largest audit firms and relatively large clients. While this should increase the generalizability to larger clients outside Finland, it may be that the changes in the environment influence smaller audit firms differently. Moreover, even if the individual Big 4 audit firms are striving to harmonize their audit approaches globally, differences across institutional settings may limit the generalizability of our results. Third, our data for year 2010 were collected by an audit firm, which granted us access to a limited set of variables. Therefore, we are unable to check the quality of the data or add additional variables. Finally, although our three different proxies for client risk (inherent risk, receivables and inventories and ownership type) illuminate the differential effects of changes in audit environment on audit effort and fees, the inconsistency in the results indicates that auditors respond differently to different risk factors.

Our results show that Big 4 audit firms reacted to the introduction of the new audit risk standards by allocating significantly more senior auditor's time to the audits of high-risk clients compared to lowrisk clients, and reduced their audit hours for their lower risk clients. Our finding that the differences in audit effort between high and low-risk companies increased significantly after introduction of audit risk standards should be of interest to the auditing profession and those involved in the development of auditing regulations. 


\section{References}

André, P., Broye, G., Pong, C., and Schatt, A. (2016). Are Joint Audits Associated with Higher Audit Fees? European Accounting Review, 25(2), 245-274. http://dx.doi.org/10.1080/09638180.2014.998016

Bell, T. F, Marrs, F. O., Solomon, I., \& Thomas, H. (1997). Auditing Organizations Through a Strategic-Systems Lens. Montvale, NJ: KPMG LLP. Retrieved from http://business.illinois.edu/files/accy/KPMG/monograph.pdf

Bell, T., Peecher, M., \& Solomon, I. (2002). The strategic systems approach to auditing. In T. Bell, \& I. Solomon (Eds.), Cases in strategic systems auditing (pp. 1-34). Montvale, NJ: KPMG.

Bell, T., Peecher, M., \& Solomon, I. (2005). The 21st Century Public Company Audit. Montvale, NJ: KPMG. Retrieved from http://www.business.illinois.edu/KPMG-uiuccases/monograph2.pdf

Bell, T., Doogar, R., \& Solomon, I. (2008). Audit labor usage and fees under business risk auditing. Journal of Accounting Research, 46, 729-760. doi: 10.1111/j.1475-679X.2008.00291.x

Breusch, T., \& Pagan, A. (1979). A Simple Test for Heteroscedasticity and Random Coefficient Variation, Econometrica, 47, 1287-1294.COSO (1992). Internal control - Integrated framework. New York, NY: AICPA.

Chu, L., Mathieu, R. \& Mbagwu, C. (2013). Audit Quality and Banks' Assessment of Disclosed Accounting Information, European Accounting Review, 22(4), 719-738. http://dx.doi.org/10.1080/09638180.2013.799740

Curtis, E., \& Turley, S. (2005). From business risk audits to audit risk standards. European Accounting Association Annual Congress, Goteborg, Sweden.

Curtis, E., \& Turley, S. (2007). The business risk audit - A longitudinal case study of an audit engagement. Accounting, Organizations and Society, 32, 439-462. doi: 10.1016/j.aos.2006.09.004

de Villiers, C., Hay, D. C., \& Zhang, J. Z. (2014). Audit Fee Stickiness. Managerial Auditing Journal, $29(1), 2-26$.

Dowling, C., Knechel, W.R., \& Moroney, R. (2015). Public oversight of audit firms: the slippery-slope of enforcing regulation. Working paper, University of Melbourne.

Efron, B., \& Tibshirani, R. (1998) An Introduction to the Bootstrap. Boca Raton, FL: Chapman and Hall.

Eilifsen, A., Knechel, W. R., \& Wallage, P. (2001). Application of the business risk audit model: A field study. Accounting Horizons, 15, 193-207. doi 10.2308/acch.2001.15.3.193

Ettredge, M., Reed, M., \& Stone, M. (2000). An examination of substitution among monitoring devices: The case of internal and external audit expenditures. Review of Quantitative Finance and Accounting, 15, 57-79. doi: 10.1023/A:1008365720747

Fama, E. F., \& Jensen M. C. (1983). Separation of Ownership and Control. Journal of Law and Economics, 26, 301-326. Retrieved from http://www.jstor.org/stable/725104 
Felix, W. L., Gramling, A. A., \& Maletta, M. J. (2001). The contribution of internal audit as determinant of external audit fees and factors influencing this contribution. Journal of Accounting Research, 39, 513-534. doi: 10.2139/ssrn.284197

Francis, J. R. (2011). A framework for understanding and researching audit quality. Auditing: A Journal of Practice \& Theory, 30(2), 125-152. doi: 10.2308/ajpt-50006

Gramling, A. (1999). External auditor's reliance on work performed by internal auditors: the influence of fee pressure on this reliance decision. Auditing: A Journal of Practice and Theory, 18 (Supplement), 117-135.

Hay, D., Knechel, W. R., \& Ling, H. (2008). Evidence on the impact of internal control and corporate governance on audit fees. International Journal of Auditing, 12, 9-24. doi: 10.1111/j.10991123.2008.00367.x

Hay, D., Knechel, W. R., \& Wong, N. (2006). Audit fees: a meta-analysis of the effects of supply and demand attributes. Contemporary Accounting Research, 23, 141-191. doi: 10.1506/4XR4-KT5VE8CN-91GX

Humphrey, C., \& Loft, A. (2013). Contemporary audit regulation - going global! In G. Caprio (Ed.), Handbook of Key Global Financial Markets, Institutions, and Infrastructure (pp. 333-343). New York, NY: Elsevier.

Humphrey, C., Loft, A., \& Woods, M. (2009). The global audit profession and the international financial architecture: understanding regulatory relationships at a time of financial crisis. Accounting, Organizations and Society, 34, 810-825. doi: 10.1016/j.aos.2009.06.003

Humphrey, C., Kausar, A., Loft, A., \& Woods, M. (2011). Regulating audit beyond the crisis: A Critical discussion of the EU Green Paper. European Accounting Review, 20, 431-457. doi: $10.1080 / 09638180.2011 .597201$

IFAC (2003). Audit Risk - Completed. Retrieved from https://www.ifac.org/auditingassurance/projects/audit-risk-completed

Jensen, M. C., \& Meckling, W. H. (1976). Theory of the Firm: Managerial Behavior, Agency Costs, and Ownership Structure. Journal of Financial Economics, 3, 305-360. doi: 10.2139/ssrn.94043

Knechel, W. R. (2013). Do Auditing Standards Matter? Current Issues in Auditing, 7, A1-A16. doi: $10.2308 /$ ciia-50499

Knechel, W. R., Salterio S. E., \& Kochetova-Kozloski N. (2010). The effect of benchmarked performance measures and strategic analysis on auditors' risk assessments and mental models. Accounting, Organizations and Society, 35, 316-333. doi: 10.1016/j.aos.2009.09.004

Knechel, W. R., \& Willekens, M. (2006). The role of risk management and governance in determining audit demand. Journal of Business Finance \& Accounting, 33, 1344-1367. doi: 10.1111/j.14685957.2006.01238.x

Lemon, W. M., Tatum, K. W., \& Turley, W. S. (2000). Developments in the audit methodologies of large accounting firms. London: ABG Professional Information.

Lennox, C. (2009). The changing regulatory landscape: editorial. International Journal of Auditing, 13, 79-85. doi: 10.1111/j.1099-1123.2009.00407.x 
Levitt, A. (2002, January 17). Who Audits the Auditors? New York Times. Retrieved from http://www.nytimes.com/2002/01/17/opinion/who-audits-the-auditors.html

Mock, T. J., \& Wright, A. (1993). An exploratory study of auditor's evidential planning judgments. Auditing: A Journal of Practice and Theory, 9, 39-61.

Mock, T. J., \& Wright, A. (1999). Are audit program plans risk-adjusted? A Journal of Practice and Theory, 18, 55-74. doi: 10.2308/aud.1999.18.1.55

Nelson, M. W. (2009). A Model and Literature Review of Professional Scepticism in Auditing. Auditing: A Journal of Practice \& Theory, 28(2), 1-34. doi: 10.2308/aud.2009.28.2.1

Niemi, L., \& Sundgren, S. (2008). Developments in auditing regulation in Finland. In R. Quick, S. Turley, \& M. Willekens (Eds.), Auditing, Trust and Governance - Developing regulation in Europe (pp. 78-97). London: Routledge.

O'Keefe, T. B., Simunic, D. A., \& Simunic, M. T. (1994). The production of audit services: Evidence from a major public accounting firm. Journal of Accounting Research, 32, 241-261. Retrieved from http://www.jstor.org/stable/2491284

Peecher, M., Schwartz, R., \& Solomon, I. (2007). It's all about audit quality: Perspectives on strategicsystems auditing. Accounting, Organizations and Society, 32, 463-486. doi: 10.1016/j.aos.2006.09.001

Robson, K., Humphrey, C., Khalifa, R., \& Jones, J. (2007). Transforming audit technologies: Business risk audit methodologies and the audit field. Accounting, Organizations and Society, 32, 409-438. doi: 10.1016/j.aos.2006.09.002

Simunic, D. A. (1980). The pricing of audit services: Theory and evidence. Journal of Accounting Research, 18, 161-190. Retrieved from http://www.jstor.org/stable/2490397

Simunic, D. A., \& Stein, M. T. (1996). The impact of litigation risk on audit pricing: A review of the economics and the evidence. Auditing: A Journal of Practice and Theory, 15 (Supplement), 119134.

Schneider, A. (1985). The reliance of external auditors on the internal audit function. Journal of Accounting Research, 23, 911-919. Retrieved from http://www.jstor.org/stable/2490849

Sloan, R. G. (1996). Do Stock Prices Fully Reflect Information in Accruals and Cash Flows About Future Earnings? Accounting Review, 71(3), 289-315.

Stein, M. T., Simunic, D. A., \& O'Keefe, T. B. (1994). Industry differences in the production of audit services. Auditing: A Journal of Practice and Theory, 13 (Supplement), 128-142.

van Buuren, J., Koch, C., van Nieuw Amerongen, N., \& Wright, A. M. (2014). The Use of Business Risk Audit Perspectives by Non-Big 4 Audit Firms. Auditing: A Journal of Practice and Theory, 33 (3), 105-128. doi: http://dx.doi.org/10.2308/ajpt-50760

White, H. (1980). A Heteroscedasticity-Consistent Covariance Matrix Estimator and a Direct Test for Heteroscedasticity. Econometrica, 48, 817-838. Retrieved from http://www.jstor.org/stable/1912934

Woolridge, J. M. (2013). Introductory Econometrics: A Modern Approach. $5^{\text {th }}$ edition. Andover: SouthWestern Cengage Learning. 
Table 1. Variable definitions

Dependent variables:

LNTOTALHOURS

Natural $\log$ (total audit hours +1 )

LNPTRMGRHOURS

LABOUR MIX

Natural $\log$ (audit hours of senior auditors (partners and managers) +1 )

LNFEES

Natural log (PTRMGRHOURS/STAFFHOURS)

Natural $\log$ of audit fees (in $€$ at 2010 values)

Other measures of audit effort ${ }^{t}$ :

LNSTAFFHOURS Natural log (audit hours of staff auditors)

PTRMGR/TOTALHRS Senior auditor hours divided by total audit hours

FEES/SALES

(Audit fees divided by net sales) *1000

HOURS/SALES

Total audit hours divided by net sales (in $€ \mathrm{~m}$ at 2010 values)

Test variables (measures of client risk):

INHRISK

Engagement partner's self-assessment of the level of overall inherent risk coded 1 for higher than average and 0 otherwise.

INVREC_HIGH Coded 1 if the sum of inventories and receivables divided by total assets exceeds the median and 0 otherwise

OWNERMANAGED

Coded 1 if $>50 \%$ owner-managed and 0 otherwise

Control variables

LNSALES

$S U B S$

ICQUALITY

Natural $\log$ of net sales for the parent (in €m at 2010 values)

Number of subsidiaries sorted into deciles (ordinal variable)

Engagement partners' assessment of overall quality of internal controls (5-point Likert scale)

$I A F$

LISTED

Coded 1 if the company has an internal audit function and 0 otherwise

MANUFACTURING

Coded 1 if the company belongs to a group listed on a stock exchange and 0 otherwise

$Y 2010$

Coded 1 if the company is in the manufacturing sector and 0 otherwise Coded 1 for year 2010 and 0 otherwise

${ }^{\dagger}$ LNSTAFFHOURS and the ratios PTRMGR/TOTALHRS, FEES/SALES and HOURS/SALES are only used in univariate tests reported in Table 2. 
Table 2. Panel A Continuous variables: Descriptive statistics and tests of difference between 1996 and 2010

\begin{tabular}{|c|c|c|c|c|c|c|c|c|c|}
\hline \multirow[b]{2}{*}{ Variables } & \multicolumn{3}{|c|}{$1996(\mathrm{n}=81)$} & \multicolumn{3}{|c|}{$2010(\mathrm{n}=59)$} & \multicolumn{3}{|c|}{$p$-values of the following tests: } \\
\hline & Mean & Median & Std. dev. & Mean & Median & Std. dev. & T-test & Wilcoxon & Eq. of variances \\
\hline LNTOTALHOURS & 5.270 & 5.429 & 1.214 & 5.064 & 4.980 & 1.200 & 0.321 & 0.127 & 0.937 \\
\hline LNPTRMGRHOURS & 4.542 & 4.883 & 1.135 & 4.147 & 4.167 & 1.586 & 0.105 & 0.144 & $0.006 * * *$ \\
\hline PTRMGR/TOTALHRS & 0.564 & 0.519 & 0.291 & 0.475 & 0.485 & 0.258 & $0.064 *$ & 0.107 & 0.341 \\
\hline LNSTAFFHOURS & 4.017 & 4.635 & 2.002 & 4.248 & 4.437 & 1.371 & 0.420 & 0.988 & $0.003 * * *$ \\
\hline LABOUR MIX & 0.525 & 0.073 & 1.897 & -0.101 & -0.062 & 1.411 & $0.027 * *$ & 0.136 & $0.018 * *$ \\
\hline$L N F E E S^{\dagger}$ & 2.867 & 3.019 & 1.142 & 3.098 & 2.996 & 1.239 & 0.256 & 0.602 & 0.492 \\
\hline$F E E S / S A L E S^{\dagger}$ & 0.374 & 0.272 & 0.384 & 0.351 & 0.238 & 0.329 & 0.701 & 0.431 & 0.215 \\
\hline HOURS/SALES $S^{\dagger}$ & 4.245 & 3.417 & 4.127 & 2.478 & 1.757 & 2.341 & $0.002 * * *$ & $<.001 * * *$ & $<.001 * * *$ \\
\hline$L N S A L E S^{\dagger}$ & 4.294 & 4.133 & 0.944 & 4.614 & 4.401 & 1.265 & 0.104 & 0.288 & $0.015 * *$ \\
\hline$S U B S$ & 5.506 & 5.000 & 2.864 & 5.559 & 6.000 & 3.064 & 0.841 & 0.919 & 0.571 \\
\hline ICQUALITY & 3.593 & 4.000 & 0.685 & 3.542 & 4.000 & 0.795 & 0.690 & 0.765 & 0.217 \\
\hline
\end{tabular}

Descriptive statistics for the variables used in the empirical tests. It also shows the results of the tests of difference $(t$-test, Wilcoxon non-parametric test, equality of variances) for the 1996 and 2010 samples. $* * * p<.001, * * p<.005, * p<.010 . P$-values are two-tailed. ${ }^{*}$ All monetary amounts are in 2010 euros. Data collected for sales and audit fees in 1996 were originally in Finnish marks. They were converted to year 2010 euros using the 2010 Consumer Index and the official exchange rate between Finnish marks and euros. FEES/SALES is presented as (audit fees divided by net sales) *1000. For example, mean audit fees equal $0.0351 \%$ of net sales in 2010 . For variable definitions, see Table 1. 
Table 2. Panel B Dichotomous variables: Descriptive statistics and tests of difference between 1996 and 2010

\begin{tabular}{lccc}
\hline Variables & Percent in $1996(\mathrm{n}=81)$ & Percent in 2010 (n= 59) & $p$-values of Fisher's exact test \\
\hline INHRISK & 16.05 & 6.78 & 0.120 \\
INVREC_HIGH & 49.38 & 47.46 & 0.865 \\
OWNERMANAGED & 24.69 & 30.51 & 0.450 \\
IAF & 44.44 & 44.07 & 1.000 \\
LISTED & 38.27 & 42.37 & 0.727 \\
MANUFACTURING & 34.57 & 37.29 & 0.858 \\
\hline
\end{tabular}

Descriptive statistics for the variables used in the empirical tests. ${ }^{* *} p<.001,{ }^{* *} p<.005,{ }^{*} p<.010 . P$-values are two-tailed. For variable definitions, see Table 1. 


\section{Table 3. Correlation matrix}

Pearson correlation year $1996(n=81)$ below the diagonal and year $2010(n=59)$ above

\begin{tabular}{|c|c|c|c|c|c|c|c|c|c|c|c|c|c|}
\hline & 1. & 2. & 3. & 4. & 5. & 6. & 7. & 8. & 9. & 10. & 11. & 12. & 13. \\
\hline 1. LNTOTALHOURS & 1 & 0.895 & 0.208 & 0.948 & 0.134 & -0.095 & -0.037 & 0.616 & 0.711 & -0.071 & -0.009 & 0.099 & 0.090 \\
\hline 2. LNPTRMGRHOURS & 0.829 & 1 & 0.587 & 0.891 & 0.133 & -0.081 & -0.075 & 0.569 & 0.680 & -0.010 & -0.097 & 0.134 & -0.062 \\
\hline 3. LABOUR MIX & -0.283 & 0.204 & 1 & 0.246 & 0.044 & -0.044 & -0.061 & 0.103 & 0.239 & 0.064 & -0.235 & 0.020 & -0.233 \\
\hline 4. LNFEE & 0.982 & 0.861 & -0.217 & 1 & 0.125 & -0.051 & -0.030 & 0.637 & 0.707 & -0.010 & -0.035 & 0.146 & 0.019 \\
\hline 5. INHRISK & 0.011 & -0.035 & 0.010 & 0.000 & 1 & 0.014 & 0.114 & -0.113 & 0.039 & -0.270 & -0.104 & -0.095 & 0.210 \\
\hline 6. INVREC HIGH & -0.120 & -0.252 & -0.086 & -0.142 & -0.096 & 1 & 0.476 & -0.078 & -0.119 & -0.137 & -0.160 & -0.128 & -0.031 \\
\hline 7. OWNERMANAGED & -0.474 & -0.371 & 0.337 & -0.450 & 0.218 & 0.179 & 1 & -0.170 & 0.023 & -0.129 & -0.370 & -0.490 & 0.098 \\
\hline 8. LNSALES & 0.393 & 0.394 & -0.066 & 0.441 & 0.047 & -0.172 & -0.257 & 1 & 0.540 & 0.093 & 0.314 & 0.275 & 0.020 \\
\hline 9. $S U B S$ & 0.120 & 0.086 & -0.079 & 0.090 & 0.111 & -0.011 & 0.109 & 0.087 & 1 & -0.162 & -0.220 & 0.079 & 0.054 \\
\hline 10. ICQUALITY & 0.250 & 0.154 & -0.169 & 0.240 & -0.282 & 0.047 & -0.162 & 0.066 & -0.110 & 1 & 0.082 & 0.193 & -0.175 \\
\hline 11. IAF & 0.065 & 0.096 & 0.027 & 0.069 & -0.188 & -0.088 & -0.224 & 0.276 & -0.037 & 0.097 & 1 & 0.344 & -0.049 \\
\hline 12. LISTED & 0.060 & 0.037 & -0.083 & 0.050 & -0.067 & -0.117 & -0.451 & 0.037 & -0.069 & 0.210 & 0.165 & 1 & -0.094 \\
\hline 13. MANUFACTURING & 0.086 & 0.159 & 0.187 & 0.109 & 0.036 & -0.147 & 0.065 & 0.034 & 0.272 & -0.099 & 0.081 & 0.069 & 1 \\
\hline
\end{tabular}

Correlations with $p$-value $<0.05$ (two-tailed) are in italics. The cut-off values for $1 \%, 5 \%$ and $10 \%$ significances (two-tailed) are $0.2155,0.1648$ and 0.1386 (respectively). For variable definitions, see Table 1. 
Table 4. Panel A Determinants of audit effort (LNTOTALHOURS): Tests of difference between 1996 and 2010 (OLS regression)

\begin{tabular}{|c|c|c|c|c|c|c|c|c|c|c|c|c|c|}
\hline Variables & $\begin{array}{l}\text { Expected } \\
\text { sign }\end{array}$ & Coeff. & $p$-val. & & Coeff. & $p$-val. & & Coeff. & $p$-val. & & Coeff. & $p$-val. & \\
\hline INTERCEPT & & - & & & - & & & - & & & - & & \\
\hline INHRISK & + & -0.040 & 0.450 & & & & & & & & 0.279 & 0.179 & \\
\hline INHRISK *Y2010 & + & 1.025 & 0.050 & $* *$ & & & & & & & 0.618 & 0.144 & \\
\hline INVREC_HIGH & + & & & & -0.142 & 0.271 & & & & & 0.039 & 0.428 & \\
\hline INVREC_HIGH*Y2010 & + & & & & 0.095 & 0.395 & & & & & -0.049 & 0.445 & \\
\hline OWNERMANAGED & - & & & & & & & -1.344 & $<.001$ & $* * *$ & -1.385 & $<.001$ & $* * *$ \\
\hline OWNERMANAGED*Y2010 & + & & & & & & & 1.205 & $<.001$ & $* * *$ & 1.217 & $<.001$ & $* * *$ \\
\hline LNSALES & + & 0.490 & $<.001$ & $* * *$ & 0.474 & $<.001$ & $* * *$ & 0.419 & $<.001$ & $* * *$ & 0.421 & $<.001$ & $* * *$ \\
\hline$S U B S$ & + & 0.097 & 0.002 & $* * *$ & 0.097 & 0.002 & $* * *$ & 0.114 & $<.001$ & $* * *$ & 0.114 & $<.001$ & $* * *$ \\
\hline ICQUALITY & $?$ & 0.221 & 0.084 & $*$ & 0.190 & 0.131 & & 0.176 & 0.124 & & 0.228 & 0.056 & $*$ \\
\hline$I A F$ & $?$ & -0.181 & 0.347 & & -0.193 & 0.319 & & -0.238 & 0.184 & & -0.208 & 0.249 & \\
\hline LISTED & + & 0.019 & 0.459 & & 0.005 & 0.489 & & -0.282 & 0.068 & & -0.292 & 0.126 & \\
\hline MANUFACTURING & $?$ & 0.090 & 0.627 & & 0.117 & 0.532 & & 0.165 & 0.335 & & 0.134 & 0.440 & \\
\hline Y2010 & $?$ & -0.434 & 0.022 & $* *$ & -0.405 & 0.101 & & -0.621 & 0.002 & $* * *$ & -0.610 & 0.011 & $* *$ \\
\hline $\mathrm{R}^{2}$ & & & 0.340 & & & 0.325 & & & 0.435 & & & 0.452 & \\
\hline $\mathrm{R}^{2}$ adj. & & & 0.295 & & & 0.279 & & & 0.396 & & & 0.396 & \\
\hline $\mathrm{n}$ & & & 140 & & & 140 & & & 140 & & & 140 & \\
\hline High vs. low client risk in 2010 & + & 0.984 & 0.071 & $*$ & -0.047 & 0.862 & & -0.139 & 0.631 & & & & \\
\hline High client risk in 2010 vs. 1996 & + & 0.591 & 0.158 & & -0.310 & 0.233 & & 0.584 & 0.031 & $* *$ & & & \\
\hline INHRISK*Y2010 + Y2010 & + & & & & & & & & & & 0.007 & 0.495 & \\
\hline INVREC_HIGH*Y2010+Y2010 & + & & & & & & & & & & -0.659 & 0.031 & $* *$ \\
\hline OWNERMANAGED*Y2010+Y2010 & + & & & & & & & & & & 0.606 & 0.080 & $*$ \\
\hline
\end{tabular}


Table 4. Panel B Determinants of senior auditor effort (LNPTRMGRHOURS): Tests of difference between 1996 and 2010 (OLS regression)

\begin{tabular}{|c|c|c|c|c|c|c|c|c|c|c|c|c|c|}
\hline Variables & $\begin{array}{l}\text { Expected } \\
\text { sign }\end{array}$ & Coeff. & $p$-val. & & Coeff. & $p$-val. & & Coeff. & $p$-val. & & Coeff. & $p$-val. & \\
\hline INTERCEPT & & - & & & - & & & - & & & & & \\
\hline INHRISK & + & -0.264 & 0.226 & & & & & & & & -0.134 & 0.705 & \\
\hline INHRISK*Y2010 & + & 1.454 & 0.017 & $* *$ & & & & & & & 1.305 & 0.028 & $* *$ \\
\hline INVREC_HIGH & + & & & & -0.427 & 0.048 & $* *$ & & & & -0.349 & 0.170 & \\
\hline INVREC_HIGH*Y2010 & + & & & & 0.342 & 0.192 & & & & & 0.364 & 0.192 & \\
\hline OWNERMANAGED & - & & & & & & & -0.916 & 0.002 & $* * *$ & -0.804 & $<.001$ & $* * *$ \\
\hline OWNERMANAGED*Y2010 & + & & & & & & & 0.681 & 0.056 & $*$ & 0.504 & 0.140 & \\
\hline LNSALES & + & 0.558 & $<.001$ & $* * *$ & 0.524 & $<.001$ & $* * *$ & 0.498 & 0.001 & $* * *$ & 0.502 & $<.001$ & $* * *$ \\
\hline$S U B S$ & + & 0.113 & 0.001 & $* * *$ & 0.115 & 0.001 & $* * *$ & 0.124 & 0.001 & $* * *$ & 0.126 & $<.001$ & $* * *$ \\
\hline ICQUALITY & $?$ & 0.148 & 0.293 & & 0.131 & 0.340 & & 0.115 & 0.392 & & 0.159 & 0.251 & \\
\hline$I A F$ & $?$ & -0.316 & 0.138 & & -0.316 & 0.138 & & -0.354 & 0.093 & $*$ & -0.357 & 0.091 & $*$ \\
\hline LISTED & + & 0.095 & 0.321 & & 0.060 & 0.385 & & -0.137 & 0.268 & & -0.141 & 0.524 & \\
\hline MANUFACTURING & $?$ & -0.041 & 0.842 & & -0.031 & 0.881 & & 0.037 & 0.854 & & -0.040 & 0.842 & \\
\hline Y2010 & $?$ & -0.700 & 0.001 & $* * *$ & -0.736 & 0.007 & $* * *$ & -0.707 & 0.002 & $* * *$ & -0.937 & 0.001 & $* * *$ \\
\hline $\mathrm{R}^{2}$ & & & 0.359 & & & 0.350 & & & 0.378 & & & 0.405 & \\
\hline $\mathrm{R}^{2}$ adj. & & & 0.315 & & & 0.305 & & & 0.335 & & & 0.344 & \\
\hline $\mathrm{n}$ & & & 140 & & & 140 & & & 140 & & & 140 & \\
\hline High vs. low client risk in 2010 & + & 1.189 & 0.049 & $* *$ & -0.085 & 0.776 & & -0.235 & 0.491 & & & & \\
\hline High client risk in 2010 vs. 1996 & + & 0.754 & 0.123 & & -0.394 & 0.168 & & -0.026 & 0.944 & & & & \\
\hline INHRISK $* Y 2010+Y 2010$ & + & & & & & & & & & & 0.368 & 0.293 & \\
\hline$I N V R E C \_H I G H^{*} Y 2010+Y 2010$ & + & & & & & & & & & & -0.572 & 0.107 & \\
\hline OWNERMANAGED*Y2010+Y2010 & + & & & & & & & & & & -0.433 & 0.390 & \\
\hline
\end{tabular}


Table 4. Panel C Determinants of LABOUR MIX: Tests of difference between 1996 and 2010

\begin{tabular}{|c|c|c|c|c|c|c|c|c|c|c|c|c|c|}
\hline Variables & $\begin{array}{l}\text { Expected } \\
\text { sign }\end{array}$ & Coeff. & p-val. & & Coeff. & $p$-val. & & Coeff. & $p$-val. & & Coeff. & $p$-val. & \\
\hline INTERCEPT & & - & & & - & & & - & & & & & \\
\hline INHRISK & $?$ & -0.108 & 0.845 & & & & & & & & -0.610 & 0.264 & \\
\hline INHRISK*Y2010 & - & 0.144 & 0.892 & & & & & & & & 0.805 & 0.440 & \\
\hline INVREC_HIGH & $?$ & & & & -0.326 & 0.411 & & & & & -0.591 & 0.131 & \\
\hline INVREC_HIGH*Y2010 & - & & & & 0.132 & 0.828 & & & & & 0.471 & 0.463 & \\
\hline OWNERMANAGED & $?$ & & & & & & & 1.572 & 0.001 & $* * *$ & 1.803 & $<.001$ & \\
\hline OWNERMANAGED*Y2010 & - & & & & & & & -1.694 & 0.010 & $* *$ & -1.884 & $<.001$ & \\
\hline LNSALES & $?$ & 0.047 & 0.762 & & 0.032 & 0.835 & & 0.113 & 0.455 & & 0.115 & 0.451 & \\
\hline$S U B S$ & $?$ & 0.004 & 0.943 & & 0.004 & 0.946 & & -0.016 & 0.767 & & -0.016 & 0.776 & \\
\hline ICQUALITY & $?$ & -0.159 & 0.470 & & -0.151 & 0.477 & & -0.139 & 0.495 & & -0.164 & 0.440 & \\
\hline$I A F$ & $?$ & -0.217 & 0.512 & & -0.224 & 0.495 & & -0.179 & 0.576 & & -0.231 & 0.476 & \\
\hline LISTED & $?$ & -0.078 & 0.807 & & -0.104 & 0.744 & & 0.221 & 0.512 & & 0.240 & 0.480 & \\
\hline MANUFACTURING & $?$ & 0.099 & 0.756 & & 0.071 & 0.824 & & 0.072 & 0.813 & & 0.005 & 0.987 & \\
\hline Y2010 & $?$ & -0.670 & 0.041 & $* *$ & -0.712 & 0.091 & $*$ & -0.255 & 0.459 & & -0.558 & 0.192 & \\
\hline $\mathrm{R}^{2}$ & & & 0.044 & & & 0.050 & & & 0.121 & & & 0.144 & \\
\hline $\mathrm{R}^{2}$ adj. & & & -0.023 & & & -0.016 & & & 0.061 & & & 0.055 & \\
\hline $\mathrm{n}$ & & & 140 & & & 140 & & & 140 & & & 140 & \\
\hline High vs. low client risk in 2010 & $?$ & 0.037 & 0.969 & & -0.194 & 0.676 & & -0.123 & 0.813 & & & & \\
\hline High client risk in 2010 vs. 1996 & $?$ & -0.526 & 0.302 & & -0.580 & 0.095 & $*$ & -1.949 & $<.001$ & $* * *$ & & & \\
\hline INHRISK $* Y 2010+Y 2010$ & $?$ & & & & & & & & & & 0.247 & 0.406 & \\
\hline INVREC_HIGH*Y2010+Y2010 & ? & & & & & & & & & & -0.087 & 0.873 & \\
\hline OWNERMANAGED*Y2010+Y2010 & $?$ & & & & & & & & & & -2.442 & 0.002 & $* * *$ \\
\hline
\end{tabular}

$\dagger$ Intercepts are not reported to preserve confidentiality. Table 4 Panel A displays the results of tests of difference between 1996 and 2010 in the magnitudes of the risk (INHRISK, INVREC_HIGH and OWNERMANAGED) for total audit hours (LNTOTALHOURS). For example, the regression coefficient $\left(\alpha_{1}\right)$ for INHRISK in 
1996 is $-0.040(p=0.450)$. The difference between the INHRISK regression coefficients in 1996 and 2010 (labelled as INHRISK $* Y 2010)$ is $\alpha_{2}=1.025(p=0.050)$. 'High vs. low client risk in 2010' is a test that $\alpha_{1}+\alpha_{2}>0$ whereas 'High client risk in 2010 vs. 1996' is a test that $\alpha_{2}+\alpha_{9}>0$ (cf. Sloan, 1996: 300). Panel B reports the results for senior audit hours (LNPTRMGRHOURS). Panel C reports the differences between senior and junior hours (i.e. $L A B O U R M I X)$. $P$-values $* * * p<.001$, ${ }^{* *} p<.005, * p<.010$ are one-tailed when expected sign, otherwise two-tailed. See Table 1 for other variable definitions. 
Table 5. Regression results: Audit fees

\begin{tabular}{|c|c|c|c|c|c|c|c|c|c|c|c|c|c|}
\hline Variables & $\begin{array}{l}\text { Expected } \\
\text { sign }\end{array}$ & Coeff. & $p$-val. & & Coeff. & $p$-val. & & Coeff. & $p$-val. & & Coeff. & $p$-val. & \\
\hline \multicolumn{14}{|l|}{ INTERCEPT } \\
\hline INHRISK & + & -0.082 & 0.393 & & & & & & & & 0.175 & 0.276 & \\
\hline INHRISK*Y2010 & + & 1.088 & 0.033 & $*$ & & & & & & & 0.763 & 0.089 & $*$ \\
\hline INVREC_HIGH & + & & & & -0.167 & 0.225 & & & & & -0.023 & 0.913 & \\
\hline INVREC_HIGH*Y2010 & + & & & & 0.218 & 0.261 & & & & & 0.108 & 0.378 & \\
\hline OWNERMANAGED & - & & & & & & & -1.121 & $<.001$ & $* * *$ & -1.134 & $<.001$ & $* * *$ \\
\hline OWNERMANAGED*Y2010 & + & & & & & & & 1.059 & 0.002 & $* * *$ & 0.987 & $<.001$ & $* * *$ \\
\hline LNSALES & + & 0.543 & $<.001$ & $* * *$ & 0.524 & $<.001$ & $* * *$ & 0.481 & $<.001$ & $* * *$ & 0.483 & $<.001$ & $* * *$ \\
\hline$S U B S$ & + & 0.086 & 0.003 & $* * *$ & 0.088 & 0.003 & $* * *$ & 0.100 & 0.001 & $* * *$ & 0.101 & $<.001$ & $* * *$ \\
\hline ICQUALITY & $?$ & 0.227 & 0.061 & $*$ & 0.203 & 0.090 & $*$ & 0.186 & 0.094 & $*$ & 0.238 & 0.040 & $* *$ \\
\hline$I A F$ & $?$ & -0.260 & 0.155 & & -0.262 & 0.154 & & -0.300 & 0.085 & $*$ & -0.278 & 0.114 & \\
\hline LISTED & + & 0.054 & 0.379 & & 0.041 & 0.409 & & -0.189 & 0.151 & & -0.203 & 0.272 & \\
\hline MANUFACTURING & $?$ & 0.051 & 0.773 & & 0.077 & 0.665 & & 0.118 & 0.476 & & 0.083 & 0.623 & \\
\hline Y2010 & $?$ & -0.022 & 0.901 & & -0.043 & 0.855 & & -0.173 & 0.353 & & -0.234 & 0.310 & \\
\hline $\mathrm{R}^{2}$ & & & 0.384 & & & 0.369 & & & 0.447 & & & 0.464 & \\
\hline $\mathrm{R}^{2}$ adj. & & & 0.342 & & & 0.325 & & & 0.409 & & & 0.409 & \\
\hline $\mathrm{n}$ & & & 140 & & & 140 & & & 140 & & & 140 & \\
\hline High vs. low client risk in 2010 & + & 1.006 & 0.026 & $* *$ & 0.051 & 0.423 & & -0.062 & 0.824 & & & & \\
\hline High client risk in 2010 vs. 1996 & + & 1.066 & 0.029 & $* *$ & 0.175 & 0.239 & & 0.886 & $<.001$ & $* * *$ & & & \\
\hline INHRISK $* 2010+Y 2010$ & + & & & & & & & & & & 0.529 & 0.174 & \\
\hline INVREC_HIGH*Y2010+Y2010 & + & & & & & & & & & & -0.127 & 0.666 & \\
\hline OWNERMANAGED*Y2010+Y2010 & + & & & & & & & & & & 0.752 & 0.074 & $*$ \\
\hline
\end{tabular}

$\dagger$ Intercepts are not reported due to confidentiality. Test of differences between 1996 and 2010 in the magnitudes of the risk (INHRISK, INVREC HIGH, and OWNERMANAGED) for audit fees $(L N F E E S)$. For example, the regression coefficient $\left(\alpha_{1}\right)$ for INHRISK in 1996 is $-0.082(p=0.393)$. The difference between the INHRISK 
regression coefficients in 1996 and 2010 (labelled as $\left.I H R I S K^{*} Y 2010\right)$ is $\alpha_{2}=1.088(p=0.033)$. 'High vs. low client risk in 2010' is a test that $\alpha_{1}+\alpha_{2}>0$ whereas 'High client risk in 2010 vs. 1996' is a test that $\alpha_{2}+\alpha_{9}>0$ (cf. Sloan, 1996: 300). $P$-values $* * * p<.001,{ }^{* *} p<.005,{ }^{*} p<.010$ are one-tailed when expected sign, otherwise two-tailed. See Table 1 for other variable definitions. 
${ }^{1}$ In 2014, this Directive was replaced by Directive 2014/56/EU.

${ }^{2}$ In 2016, the AB3C was replaced by a new supervisory body under the auspices of the Finnish Patent and Registration Office.

${ }^{3}$ Bell et al. (2008) analyse changes prior the effective date of Sarbanes-Oxley Act of 2002 (SOX) and related regulations (p. 731, footnote 4).

${ }^{4}$ The term 'strategic systems auditing' was also used by some of the researchers responding to the monograph published by KPMG (Bell, Marrs \& Solomon, 1997; 2002; 2005).

${ }^{5}$ A common factor of the accounting scandals in the early 2000s was fraudulent financial reporting. This wave of management-related frauds led to an increase in the auditors' responsibility for detecting fraud by management. An example of this regulatory response was the introduction of ISA 240, The Auditor's Responsibilities Relating to Fraud in an Audit of Financial Statements (IAASB, 2009), which sensitizes auditors to the risk of fraudulent reporting and causes them to be less willing to accept management's assertions at face value.

${ }^{6}$ In the early 1990s, Finland experienced a deep recession with many business failures and alleged audit failures. This led to questions about the quality of the audit. The Finnish professional associations of auditors reacted to the adverse publicity by initiating quality assurance programmes based on voluntary peer-reviews.

7 The move from voluntary peer review to mandatory inspections by oversight bodies was instigated by the Statutory Audit Directive (2006/43/EC) in 2006 which required Member States to establish an effective system of public oversight for statutory auditors and audit firms. The Statutory Audit Directive was implemented in the Finnish Auditing Act 2007.

${ }^{8}$ This pressure seems warranted as sanctions of non-compliance are high. For example, AB3C in Finland now inspects the quality of audit work systematically and rejection leads to a re-inspection. Auditors who fail the re-inspection run the risk of having their authorization to conduct statutory audits withdrawn. In 2013, there were two cases where the Auditing Board of the State (ABS) cancelled the auditor's right to conduct audits (TILA 5/2013; TILA 6/2013).

${ }^{9}$ The report does not contain information about identities of auditors or the names of the firms. However, we base our conclusion to the information that almost all auditors not passing the quality inspections were second tier HTM-auditors, who typically work in small firms focusing on small clients.

${ }^{10}$ The Auditing Act of 1994 (936/28.10.1994) was effective for all audits of 1996 year-end financial statements (the year of our initial data).

${ }^{11}$ The Big 6 were Arthur Andersen, Coopers \& Lybrand, Deloitte, EY, KMPG, and Price Waterhouse.

12 The 1996 data were collected in 1997.

${ }^{13}$ The Big 6 were reduced to the Big 4 following the merger of Coopers \& Lybrand with Price Waterhouse in 1998 and the collapse of Arthur Andersen in 2002.

${ }^{14}$ In our additional analyses, we also employ audit fees (LNFEES) as a dependent variable to test whether additional effort is reflected in the audit price. We use the total audit fees as we do not have information on billing rates for different ranks of labour.

${ }^{15}$ However, agency conflicts among managers (principals) and between managers and subordinates may be higher in owner-managed firms than other ownership types. We thank the anonymous reviewer for pointing this out.

${ }^{16}$ For reasons of confidentiality, we do not know the precise ownership level.

${ }^{17}$ In our test design, the coefficient $\left(\alpha_{1}\right)$ of CLIENT_RISK shows the difference between high and low client risk in 1996 and the difference between high and low client risk firms in 2010 is given by $\alpha_{1}+\alpha_{2}$.

${ }^{18}$ The most common measure of client size is natural logarithm of total assets (Hay, Knechel \& Wong, 2006). However, we use net sales to allow comparison with our 1996 data. The 2010 data were collected by one audit firm according to our instructions.

${ }^{19}$ To ensure anonymity, SUBS is the number of subsidiaries sorted into deciles (ordinal variable). 
${ }^{20}$ This allows us to conserve degrees of freedom given our small sample size. We feel this is justified because the mean and median for these variables are not statistically different between 1996 and 2010.

${ }^{21}$ Data collected for sales and audit fees in 1996 were originally in Finnish marks. They were converted to euros using the 2010 Consumer Index and the official exchange rate. This means that any changes in sales and audit fees were not due to inflation or deflation.

${ }^{22}$ For comparison, André et al. (2016) report the ratio of the audit fee/assets percentage of $0.042 \%$ for Italian companies over 2007-2011 period.

${ }^{23} \mathrm{We}$ also re-run the tests of the equality of variances with a sample where we drop the 2010 observations with the highest absolute values of centred LNSALES and trigger the difference variance between 1996 and 2010 for LNSALES in the full sample. We then find that the variance of LNSALES between 1996 and 2010 is statistically equal. After this resampling, we still obtain the same empirical results: the variance of junior auditor time (senior auditor time) decreased (increased) from 1996 to 2010 .

${ }^{24}$ We also calculated Spearman correlations, which are consistent with reported Pearson correlations.

${ }^{25}$ We do not find heteroscedasticity using the White test (White, 1980) and the Breusch-Pagan test (Breusch \& Pagan, 1979) in any of the models used to test the hypotheses. Nevertheless, we also calculate robust standard errors. The results remain qualitatively the same with robust standard errors.

${ }^{26}$ The dependent variable (audit hours) and client size (sales), are natural logarithms while the test variables are in their original metric. This means that our untransformed original dependent variable changes by $100 *\left(\mathrm{e}^{\wedge} \propto-1\right)$ per cent for a one unit increase in the independent variable when all other variables in the model are held constant (Woolridge, 2013).

${ }^{27}$ Note that $\operatorname{Ln}(\mathrm{A})-\operatorname{Ln}(\mathrm{B})=\operatorname{Ln}(\mathrm{A} / \mathrm{B})$. 